\title{
Factors for the design of novel property-level flood resilient products: the Dado Wallboard
}

\author{
D. W. Beddoes ${ }^{1,2}$ \& C. A. Booth ${ }^{1}$ \\ ${ }^{I}$ Department of Construction and Property, \\ University of the West of England, Bristol, UK \\ ${ }^{2}$ DrainAngel Ltd., Shropshire, UK
}

\begin{abstract}
Community-level flood protection cannot guarantee property owners are free from flood risk, hence, it is the responsibility of property owners themselves to take appropriate action to ensure their properties are suitably protected by flood resistant and/or flood resilient measures. There are many flood products and avenues available for property owners to choose. This article introduces and describes the new Dado Wallboard property-level flood resilient product. It offers several practical advantages over existing internal building designs and fabrics, namely: (i) it is made from waterproof material and, as such, does not need to be replaced when a building has been flooded; (ii) it is mechanically fixed to the building wall substructure so that it remains in place when immersed in floodwater; and (iii) a movable dado rail and movable skirting board allow access into the cavity formed between the dado board and wall substructure and this allows both sides of a wall to be dried simultaneously. The product also offers socio-economic benefits, namely: (i) it reduces post-flood building reinstatement costs because fabric replacement is not necessary; and (ii) the wall drying procedure may reduce the overall time buildings are unoccupied. Keywords: property adaptation, flood resistance and resilience, patent product.
\end{abstract}

\section{Introduction}

Flooding is one of the most dangerous and challenging issues facing humankind [1] and the catalogue of recent global disasters serve to exemplify this problem (e.g. Thailand (2011), Pakistan (2010), UK (2007) and the USA (2005), amongst many others). Effects of climate change on the built environment [2], coupled 
with increased societal pressure to further develop on floodplains, is overloading existing infrastructure and facilitating an increase in flood events. The impacts of these events can frequently encompass tragic loss of life and damage to both built and natural environments, plus massive insurance flood-repair claims [3, 4], considerable commercial businesses losses [5] and lengthy social disruption for property owners [6]. Therefore, governments and planning authorities are confronted with addressing the issues through suitable management strategies and appropriate legislation (e.g. Floods and Water Management Act (2010) in the UK) and through informed 'best practice' advice to property owners.

Where properties are known to be in a flood risk area, rather than ignore the situation and wait for a flood event to happen, there is an opportunity for property builders and/or owners to install flood resistance and/or flood resilience measures outside and/or inside buildings [7, 8]. Flood resistance measures attempt to halt floodwater entry into a property to prevent floodwater damaging its fabric $[9,10]$. In contrast, flood resilience measures permit floodwater entry because the property is designed and constructed in a manner that floodwater impact is minimised, with no permanent damage caused, structural integrity maintained and subsequent drying and cleaning are easily facilitated [10].

This paper describes existing flood protection approaches used to adapt properties and outlines available property-level flood protection products, before introducing and detailing a novel flood resilient product (patent pending).

\section{Existing flood protection measures}

There are wide variations in the ways that people respond to probabilistic hazard forecasting, such as flooding, with some people making extensive preparation and others taking no action [11]. Unfortunately, there remains a very low take-up of property level flood protection. Surveys have shown that only a third of people who have experienced a flood take steps to protect their properties. This is mainly linked to concerns about: (i) perceived affordability of adaptation; (ii) anticipated impacts on property values; (iii) perceived costs and benefits of insurance; and (iv) social and emotional issues, such as anxiety, blame and regret, stigma and social identity [12].

It is recognised that flood protection products (Tables 1-3) need to be designed in such a way they not only protect properties from damage but also make the owner feel they are protected [12]. Flood protection choices for existing properties are between resistance and resilience measures, or a combination of both. External resistance measures are mostly acceptable to property owners but they do not always offer full protection; whereas, resilience measures are not a preferred choice for property owners, despite the benefits offered [13]. Minimising internal property damage is an obvious financial benefit but minimising the social disruption, by reducing the duration of the repair and reinstatement time, is an immense benefit for property owners because it clearly lessens the length of time spent away from the property. This is because flood resilience features offer the advantage to property owners that they can return and continue normal activities, after drying and cleaning, within a matter of days 
or weeks, as opposed to several months or sometimes more than a year after a flood event [8] or, in some cases, even two years [14]. Therefore, there is a need for sustained growth in the range of appealing and affordable flood resilient products for property owners to choose, without the attachment of emotional issues.

Table 1: Examples of permanent property-level flood resistant measures [15].

\section{Permanent Flood Resistant Measures}

1. Earth bund walls;

2. Periphery fences with sealed gates;

3. Raising building thresholds;

4. Storm porches to external doors;

5. External flood resistant doors;

6. Periscope or self-closing airbricks;

7. Anti-backflow valves on sewers;

8. Automatic activating external door guards;

9. Adding a water resistant render or extra skin of engineering bricks.

Table 2: Examples of temporary property-level flood resistant measures [15].

\section{Temporary Flood Resistant Measures}

1. Air-brick covers;

2. External door guards;

3. Flood skirts;

4. Mains unit flood alarms.

Table 3: $\quad$ Examples of property-level flood resilient measures [15].

\section{Flood Resilient Measures}

1. Internal tanking;

2. Concrete and tiled floors;

3. Raised electrical sockets and service meters;

4. Horizontal replacement plasterboard;

5. Resilient kitchen units (plastic, stainless steel, free standing, removable);

6. Raised kitchen appliances (ovens, fridges, freezers, washing machines);

7. Resilient internal walls (rendered, tiled, coated);

8. Plastic skirting board;

9. Plastic or acrylic internal doors or fitted with rising butt hinges;

10. Pump and sump systems. 


\section{Announcing a novel property-level flood-resilient product}

The amount of damage caused to a building in a flood event is proportional to the depth of floodwater and the time the building is subjected to the floodwater [9]. In the case of a short duration flood event, external resistance measures such as 'door guards' can prevent some floodwater from entering a building but they cannot be safely used when floodwater depth exceeds $600 \mathrm{~mm}$ because of the risk of structural damage [16]. When the differential height between building floor level and the height of the floodwater is over $600 \mathrm{~mm}$ the hydrostatic water pressure can cause structural damage to the walls of the building and so the floodwater must be allowed to enter the building. Once the floodwater has entered the building the owners must wait for the floodwater to recede before beginning the clean-up and drying process to allow reoccupation.

Cleaning the building is relatively easy but drying out a building after floodwater has entered is a major problem [17]. Typically, the type of construction that needs drying out comprises sand/cement screeds, thick masonry walls, wooden skirting boards and gypsum plaster. Very often the gypsum plaster becomes damaged by the water and also contaminated by floodwater contents and so has to be completely removed. The wall substructure must then be dried out before re-plastering and then the new plaster has to dry out. Drying of wall construction takes a long time and whilst being dried the building has to remain unoccupied e.g. typical masonry construction dries at the rate of $1 \mathrm{~mm}$ per day so that a $300 \mathrm{~mm}$ thick wall takes several months to dry out. To overcome this, the present invention proposes a dado wallboard that forms a cavity against the wall substructure; an aperture at floor level allows access into the cavity for forced convective gas that constrained within the cavity passes directly across the surface of the wall substructure before exiting the cavity through another aperture part way up the wall.

Current drying methods comprise the removal of all the plaster on affected walls and then natural air drying whereby the wall substructure is dried with air circulated around the room to use natural drying potential. The process is very slow and weather dependent. It is a complex process involving consideration of room air temperature, relative humidity in the room, moisture content of wall substructure and temperature of the wall substructure being dried. An initial linear reduction of the wall substructure moisture content as a function of time the 'constant drying rate period' will give way to a 'falling rate period' and the time taken for drying increases accordingly. Directly applied heated gas convection will decrease the "constant drying rate period and lessen the "falling rate'.

Forced heated convective gas is blown into the cavity at floor level and passes directly across the surface of the wall substructure to increase the driving force for heat transfer and accelerate drying. Passing the heated convective gas intimately across the wall substructure also reduces air relative humidity that further increases the driving force for drying. Passing the heated convective gas intimately across the wall substructure will heat up the wall substructure and this higher temperature will speed up diffusion of water from the inside of the wall to 
the surface and so maintain a more continuous drying rate to accelerate the drying. The convective gas exits the cavity at the top of the dado board and as such is at the required height for leaving the room via an open window, so forcing the convective gas through the floor aperture and up through the cavity and then out via a window can be a rapid, efficient, whole room convective cycle for accelerated drying as opposed to the typical slow drying due to room air that is heavily moisture laden and re-circulated around the room.

The installation of the dado wallboard will look quite normal to the occupiers of the building. The dado wallboard can be finished with waterproof plaster and paint, the movable dado rail and skirting will both appear as normal. There will be no visual stigma associated with the dado board installation.

After the cavity and wall substructure has been sanitised via the apertures, and subsequently dried by forced heated convection, the room can be returned to use simply by replacement of dado rail and skirting boards, there is no need for re-plastering. The aperture formed between top of dado rail and normal wall covering can be set at any height required as long as it is above predicted floodwater heights. Typically when waterproof membranes are installed in wall construction and the floodwater is let into a building the floodwater manages to seep between the layers of construction. A film or layer of contaminated floodwater can become trapped between wall substructure and membrane and/or wall finishing materials and membrane. Often this contaminated water cannot be removed without first having to remove the wall finish (plaster) and/or membrane. The dado wallboard system renders all this remedial work unnecessary because removal of dado rail and skirting allows sanitising fluid to be introduced via the dado rail aperture into the cavity between the dado board and the wall substructure. The rear of the dado board and the surface of the wall substructure can both be accessed and sanitised with sanitising fluid flushing down the cavity and passing under the floor membrane to the sump/pump unit so that it can be pumped out of the building.

When floodwater levels are below $600 \mathrm{~mm}$ the cavity formed between the wall substructure and the rear of the dado wallboard will collect any floodwater that passes through imperfections or faults within the wall at a higher level and ensure it falls downwards to the floor membrane for subsequent removal by the sump/pump unit. The cavity formed behind the dado wallboard can be used to house wall insulation. As part of the dado wallboard installation the building could be upgraded and fitted with wall insulation e.g. a closed cell insulation could be inserted behind the dado wallboard and removed for cleaning via the dado aperture in the event of a flood.

\section{Detailed and diagrammatic descriptions of the product}

The product, which is pending patent, is described and illustrated beneath Figure 1 is a cross-sectional drawing to show the dado wallboard W. The drawing shows a building where the floodwater has reached a level that may cause structural damage and so the floodwater has been let into the rooms of the 


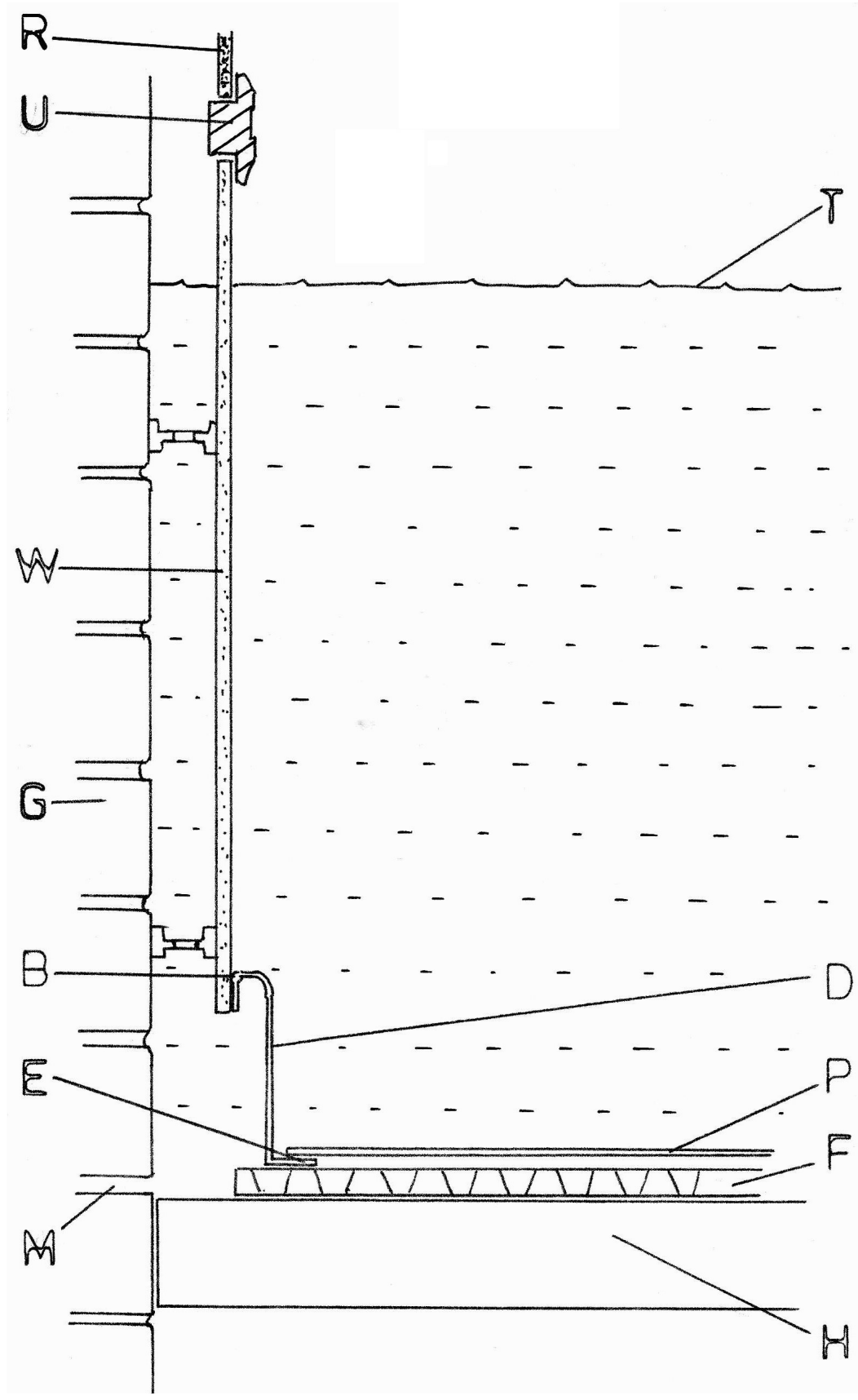

Figure 1: Cross-sectional drawing to show the dado wallboard fitted to a building and the floodwater has been allowed into the building. 
building. The level of floodwater inside the building shown as $\mathrm{T}$ is now the same as the floodwater level on the outside of the building. The wall substructure shown as $\mathrm{G}$ is in this case masonry construction. The hole $\mathrm{M}$ is drilled through the inner skin of the wall to drain water from the centre of a solid wall or from a wall cavity. The waterproof dado wallboard $\mathrm{W}$ is mechanically fixed to the wall substructure. There is a removable or movable dado rail $U$ fitted into or covering the aperture between the top of the waterproof dado wallboard and the conventional wallboard $\mathrm{R}$. The aperture at the bottom of the dado wallboard is covered by the skirting board D that is fitted to the dado wallboard at B and the building floor at $\mathrm{E}$. The floor covering $\mathrm{P}$ is laid over a floor membrane $\mathrm{F}$ that sits on floor construction $\mathrm{H}$. The floodwater shown at level $\mathrm{T}$ fills the rooms within the building and the cavity formed between the surface of the wall substructure and the rear face of the waterproof dado board $\mathrm{W}$.

Figure 2 is a cross-sectional drawing to illustrate the sanitising process of the wall structure after the floodwater has receded. The dado rail $\mathrm{U}$ is removed and aperture $\mathrm{V}$ allows access into the top of the cavity, similarly the skirting board is moved or removed to provide the aperture between dado wallboard and floor for access into the cavity between wall substructure and dado wallboard. Sanitising fluid $\mathrm{C}$ is introduced with applicator A into the cavity. Sanitising fluid is flushed into the cavity, as shown by arrows $\mathrm{K}$, and completely cleans the cavity area including the surface of the wall substructure, the rear of the dado wallboard and any mechanical fixings in the cavity. The used sanitising fluid exits the cavity at $\mathrm{L}$ and passes under membrane $\mathrm{F}$ to a sump/pump unit for removal from the building. The dado rail and the skirting board can be movable or completely removable, all that matters is that access can be gained into the cavity by the apertures above and below the dado wallboard. The existence of the cavity and access into it makes it possible to sanitise and rapidly dry the structure. A waterproof membrane could also be incorporated into the wall construction but such a membrane must be of adequate profile and its location must be carefully considered so that it can be accessed for sanitising and drying i.e. the waterproof membrane if installed must not be able to harbour an inaccessible trapped layer of contaminated floodwater within the wall.

Figure 3 is a cross-sectional drawing to show the drying process of the wall structure after it has been sanitised. The forced hot convective gas $\mathrm{S}$ is entering the cavity via the lower aperture after the skirting has been moved. Some gas will enter via holes $M$ to dry the wall and/or the wall cavity but the majority will travel up the cavity between the wall substructure and the rear of the dado wall board drying out the wall substructure and exiting through aperture $\mathrm{V}$ which is part way up the wall where the dado rail has been removed. The moisture laden gas leaving the cavity through aperture $\mathrm{V}$ is at a convenient height to then pass out of the building through an open window and set up a whole room convection cycle for accelerated drying. After drying out is complete the cavity can have any insulation replaced behind the dado wallboard by access through the apertures before the dado rail and skirting are refitted. 


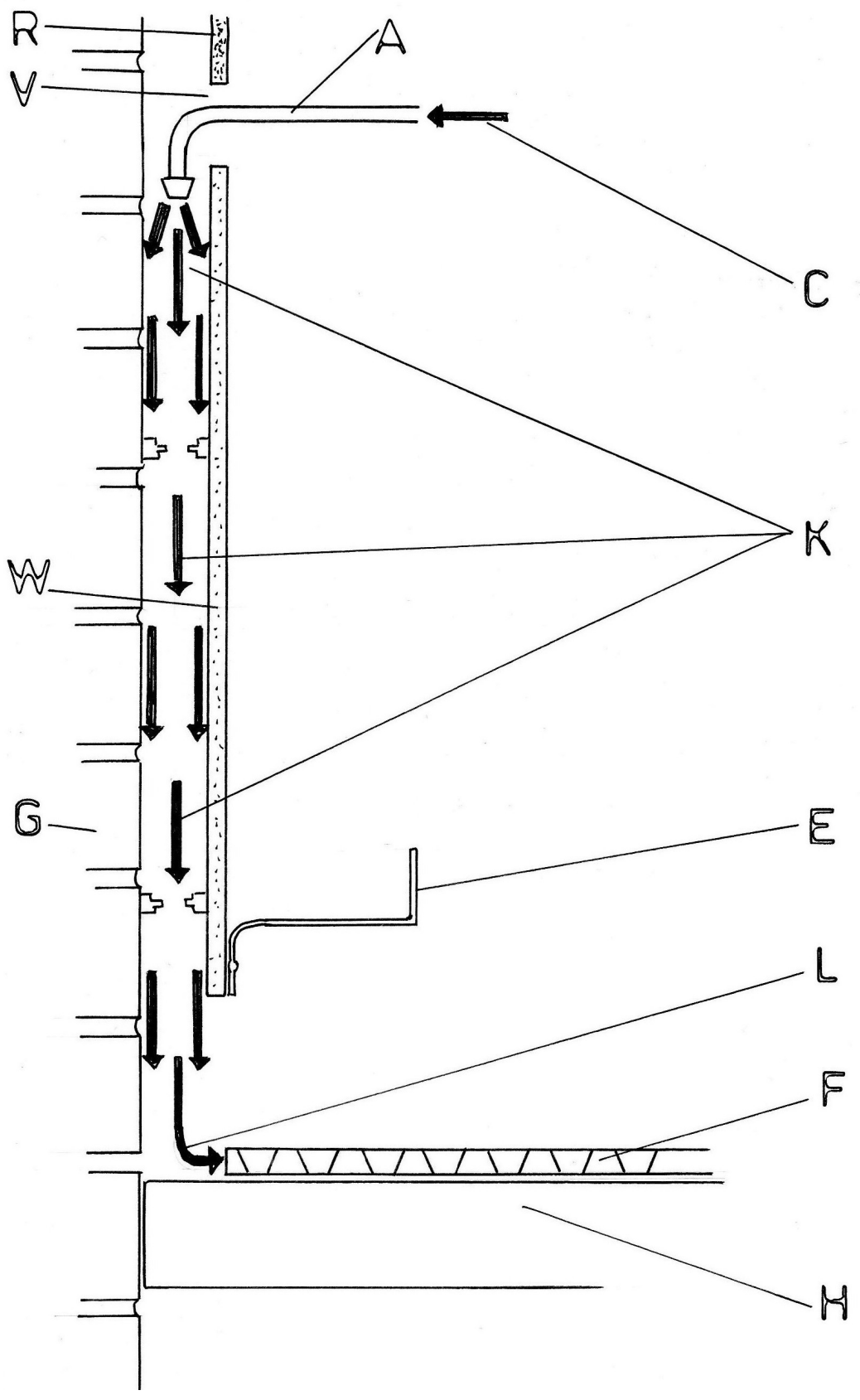

Figure 2: Cross-sectional drawing to illustrate the sanitising process of the wall structure after the floodwater has receded. 


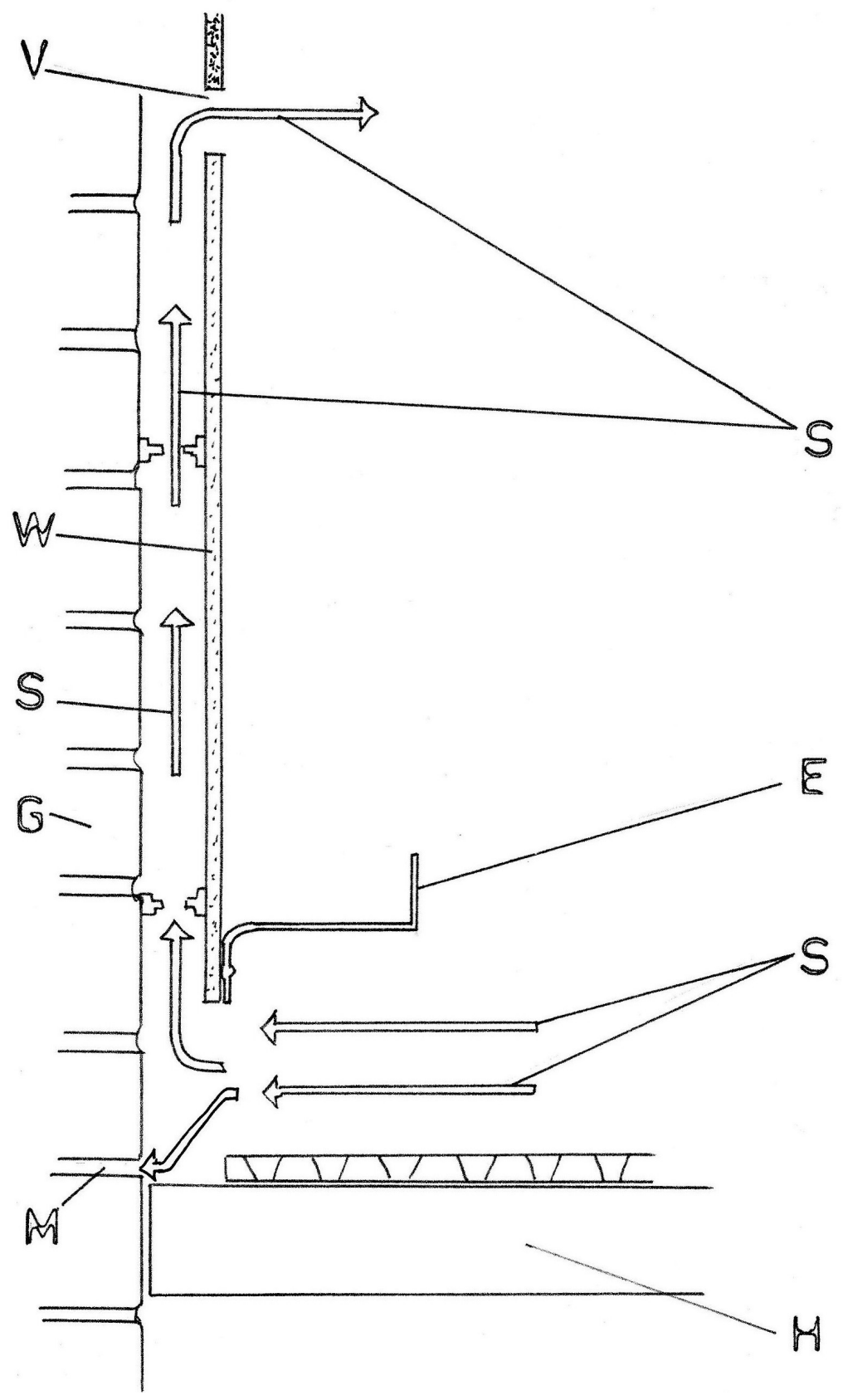

Figure 3: Cross-sectional drawing to show the drying process of the wall structure after it has been sanitised. 


\section{Comparable costs and benefits}

Overriding determinants of product success are dependent upon cost and benefit. The costings [18] of three scenarios are described for the reinstatement of a standard ground floor room $(4 \mathrm{~m} \mathrm{x} 4 \mathrm{~m})$ in a typical house that has been flooded to a depth of one metre. The first scenario (Table 4) is reinstatement to the original specification, the second scenario (Table 5) is reinstatement with a suite of flood resilient measures (as currently used by the flood repair industry) and the final scenario (Table 6) is reinstatement with dado wallboard flood protection.

Table 4: Scenario one - reinstatement of the room to the original specification - totalling $£ 1937.60$ [18].

\begin{tabular}{|c|c|c|c|c|c|}
\hline Ref & Description & Quantity & Unit & Rate & Value $£$ \\
\hline 1 & $\begin{array}{c}\text { Woodwork repairs and } \\
\text { removals }\end{array}$ & 16 & $\mathrm{~m}^{2}$ & 7.13 & 114.08 \\
\hline 2 & $\begin{array}{c}\text { Install new treated joists and } \\
\text { floorboards }\end{array}$ & 16 & $\mathrm{~m}^{2}$ & 73.06 & 1168.96 \\
\hline 3 & Floor, wall and ceiling finishes & 16 & $\mathrm{~m}^{2}$ & 36.41 & 582.56 \\
\hline 4 & Sundries-electrical work & 3 & each & 16.00 & 48.00 \\
\hline 5 & TV outlet & 1 & each & 24.00 & 24.00 \\
\hline
\end{tabular}

Table 5: Scenario two - reinstatement of the room with a suite of resilient measures - sub-totals at $£ 2681.10$ (plus the prime cost sum of $£ 3000$, totals £5681.10) [18].

\begin{tabular}{|l|l|c|c|c|c|}
\hline Ref & Description & Quantity & Unit & Rate & Value $£$ \\
\hline 1 & $\begin{array}{l}\text { Woodwork repairs and removal, } \\
\text { plus sleeper walls and bake }\end{array}$ & 16 & $\mathrm{~m}^{2}$ & 7.13 & 114.08 \\
\hline 2 & $\begin{array}{l}\text { Excavation, earthwork and } \\
\text { concrete work. }\end{array}$ & 16 & $\mathrm{~m}^{2}$ & 2.04 & 32.64 \\
\hline 3 & Filling with imported hardcore & 24 & $\mathrm{~m}^{2}$ & 15.74 & 377.76 \\
\hline 4 & Surface treatments & 16 & $\mathrm{~m}^{2}$ & 1.80 & 28.80 \\
\hline 5 & Expanded polystyrene board & 16 & $\mathrm{~m}^{2}$ & 8.90 & 142.40 \\
\hline 6 & Polythene damproof membrane & 16 & $\mathrm{~m}^{2}$ & 1.39 & 22.24 \\
\hline 7 & In situ concrete floor slabs & 16 & $\mathrm{~m}^{2}$ & 211.80 & 508.32 \\
& per $\mathrm{m}^{3}$ & \\
\hline 8 & Cement screeds & 16 & $\mathrm{~m}^{2}$ & 30.06 & 480.96 \\
\hline 9 & Cement finishes - dubbing out & 8 & $\mathrm{~m}^{2}$ & 6.18 & 49.44 \\
\hline 10 & $\begin{array}{l}\text { Cement finishes - including } \\
\text { additive }\end{array}$ & 16 & $\mathrm{~m}^{2}$ & 40.02 & 640.32 \\
\hline 11 & Sundries-electrical work & 3 & $\mathrm{~m}^{2}$ & 50.02 & 150.06 \\
\hline 12 & TV outlets & 1 & $\mathrm{each}^{2}$ & 54.08 & 54.08 \\
\hline 13 & $\begin{array}{l}\text { Sump and pump unit, plus } \\
\text { sewer backflow valve }\end{array}$ & 1 & $\mathrm{sum}$ & 2000.00 & 2000.00 \\
\hline 14 & Aperture doorguard & 1 & $\mathrm{sum}$ & 1000.00 & 1000.00 \\
\hline
\end{tabular}


Table 6: Scenario three - reinstatement of the room with dado wallboard flood protection - sub-totals at $£ 2553.74$ (plus the prime cost sum of $£ 3000$ totals $£ 5553.74)$ [18].

\begin{tabular}{|c|c|c|c|c|c|}
\hline Ref & Description & Quantity & Unit & Rate & Value $£$ \\
\hline 1 & $\begin{array}{l}\text { Woodwork repairs and } \\
\text { removal, plus sleeper walls } \\
\text { and bwk }\end{array}$ & 16 & $\begin{array}{l}\mathrm{m}^{2} \\
\text { sum }\end{array}$ & $\begin{array}{r}7.13 \\
80.00\end{array}$ & 114.08 \\
\hline 2 & $\begin{array}{l}\text { Excavation, earthwork and } \\
\text { concreting }\end{array}$ & 16 & $\mathrm{~m}^{2}$ & 2.04 & 32.64 \\
\hline 3 & $\begin{array}{l}\text { Filling with imported } \\
\text { hardcore }\end{array}$ & 24 & $\mathrm{~m}^{2}$ & 15.74 & 377.76 \\
\hline 4 & Surface treatments & 16 & $\mathrm{~m}^{2}$ & 1.80 & 28.80 \\
\hline 5 & $\begin{array}{l}\text { Expanded polystyrene } \\
\text { board }\end{array}$ & 16 & $\mathrm{~m}^{2}$ & 8.90 & 142.40 \\
\hline 6 & $\begin{array}{l}\text { Polythene damproof } \\
\text { membrane }\end{array}$ & 16 & $\mathrm{~m}^{2}$ & 1.39 & 22.24 \\
\hline 7 & In situ concrete floor slabs & 16 & $\mathrm{~m}^{2}$ & $\begin{array}{l}211.80 \\
\text { per } \mathrm{m}^{3}\end{array}$ & 508.32 \\
\hline 8 & $\begin{array}{l}\text { Floor, wall and ceiling } \\
\text { finishes }\end{array}$ & 16 & $\mathrm{~m}^{2}$ & 6.87 & 109.92 \\
\hline 9 & $\begin{array}{l}\text { Insulation for laminate floor } \\
\text { panels }\end{array}$ & 16 & $\mathrm{~m}^{2}$ & 8.08 & 129.28 \\
\hline 10 & Dry-lining and partitions & 16 & $\mathrm{~m}^{2}$ & 43.50 & 696.00 \\
\hline 11 & $\begin{array}{l}\text { Woodwork and UPVC } \\
\text { second fixings. }\end{array}$ & 16 & $\mathrm{~m}$ & 6.76 & 108.16 \\
\hline 12 & Sundries-electrical work & 3 & $\mathrm{~m}^{2}$ & 50.02 & 150.06 \\
\hline 13 & TV outlets & 1 & each & 54.08 & 54.08 \\
\hline 14 & $\begin{array}{l}\text { Sump and pump unit, plus } \\
\text { sewer backflow valve }\end{array}$ & 1 & sum & 2000.00 & 2000.00 \\
\hline 15 & Aperture doorguard & 1 & sum & 1000.00 & 1000.00 \\
\hline
\end{tabular}

For simplicity, the following assumptions are inferred; the room has a suspended timber floor with tongue and groove boarding, the walls are 'Gyproc' two coat wet plaster finish, electrics are three dual sockets with single TV point and any items that are common to all three scenarios (e.g. floor finishes, hacking off water damaged plaster, skirting boards and architraves) are not included in the cost comparisons. Also, the 'prime cost sum` for installation of a sump/pump unit and sewer backflow valve has been entered (£2000) but a wide variation in costs exist [19]. Similarly, the 'prime cost sum' for the aperture guard entered (£1000) can vary [20,21].

The costings for the three scenarios show the least expensive option is to reinstate the room to its original specification; however, this cost must be met each time a flood event occurs. Furthermore, there will be sizeable costs associated with re-housing the flood victims (for several months) whilst all the works and extensive drying out periods are in progress [22]. Scenario two, 
reinstating the room with a suite of resilient measures (plus prime cost products), is more expensive but there are additional benefits because the insulated floor will not need replacement in the event of another flood and resilient walls together with a sump/pump afford some protection against low rates of water ingress. Scenario three, reinstating the room with dado wallboard flood protection costs slightly less than scenario two and offers many benefits for the homeowner. For instance, compared with scenario two, the homeowner will not be expected to sweep water ingress across the floor as it will pass under the floor membrane that is laid onto the concrete slab and then to the sump for removal.

There will be no rising damp in the walls as a result of water from below floors as a cavity is retained between wall and waterproof dado wall which can be ventilated via the skirting board and/or dado rail. In a flood event the system addresses residual risk as even when the differential height exceeds $600 \mathrm{~mm}$ and water is allowed into the dwelling (achieved by letter box sited in door transom) there will be minimal damage if the floodwater stays below the designed dado rail height. The dado wallboard will allow quick and easy drying of the structure and the floor membrane with laminated floor finish are sacrificial at a cost of around two hundred and forty pounds. Dwellings with very porous external elements and/or Radon issues can incorporate perimeter floor drains to manage higher rates of water ingress at a cost of around two hundred pounds for the room as considered in this example.

\section{Discussion}

Floods are the most destructive natural disaster to affect humans [17], so it is important to remember the human misery and suffering caused by flood events. The majority of property owners who live in high-risk flood areas have not yet adopted any flood protection despite the high profile attention given to flood events by the media [23]. For instance, a leading insurance company, Norwich Union, recently surveyed $1500 \mathrm{UK}$ flood victims and found most still believe there is nothing they can do to mitigate future flooding [24]. This is further supported by a survey conducted for the Department for Environment Food and Rural Affairs (DEFRA), which found, in areas of significant flood risk, only a small number of homeowners had taken any practical steps to limit potential flood damage [25]. Even those living in properties flooded several times before have taken only minimal action, often installing measures that are ineffective [25]. To address these issues, in 2011, the UK Government provided funding in excess of $£ 2$ million to protect 600 households based in 30 communities. Furthermore, in late 2011, the Environment Agency (EA) announced new grant aid of $£ 1.3$ million for a further 37 communities in England that are at risk of flooding, and this money is to be used to assist 500 homeowners wanting the installation of products to provide property level flood protection. More recently, the Flooding Minister (Richard Benyons MP) also promised at least another $£ 2.1$ billion will be spent on flood defence over the next four years [26].

In order to make the decision to install flood protection measures, the property owner must have both the desire to act and the ability to act [27]. 
Dhonau and Lamond [14] have detailed several case studies where property owners have eventually done something to minimise any future damage they may suffer; albeit, in one example, after suffering three floods in seven years and after being displaced for two years from their property. Nonetheless, by undertaking common flood resilience measures (Table 3) and creating some of their own (e.g. lightweight and easy to move furniture), they have accepted the problem is not going to disappear and they have now clearly had both the desire and ability to act. The case studies [14] highlight there are many ways to improve property-level flood resilience and the steps people are willing to take, and although the Dado Wallboard is just another flood resilience product, in addition to those already mentioned, if it is utilised by just one property owner and it reduces their damage and disruption, the authors will be duly satisfied.

\section{Conclusions}

The Dado Wallboard product demonstrates several practical advantages over those of existing internal building designs and fabrics, namely: (i) it is made from waterproof material and, as such, does not need to be replaced when a building has been flooded; (ii) it is mechanically fixed to the building wall substructure so that it remains in place when immersed in floodwater; and (iii) a movable dado rail and movable skirting board allow access into the cavity formed between the dado board and wall substructure and this allows both sides of a wall to be dried simultaneously. The product also offers socio-economic benefits, namely: (i) it reduces post-flood building reinstatement costs because fabric replacement is not necessary; and (ii) the wall drying procedure may reduce the overall time buildings are unoccupied.

\section{References}

[1] Lamond, J.E., Booth, C.A., Hammond, F. and Proverbs, D.G. (2011) Flood Hazards: Impacts and Responses for the Built Environment. CRC Press Taylor and Francis Group, London.

[2] Booth, C.A., Hammond, F., Lamond, J.E. and Proverbs, D.G. (2012) Solutions to Climate Change Challenges for the Built Environment. WileyBlackwells, Oxford.

[3] Surminski, S. (2011) Flood insurance in the United Kingdom: the Association of British Insurers. In: Lamond, J.E, Booth, C.A., Hammond, F. and Proverbs, D.G. (Editors) Flood Hazards: Impacts and Responses for the Built Environment. CRC Press - Taylor and Francis Group, London, 8997.

[4] Blanchard-Boehm, R.D., Berry, K.A. and Showalter, P.S. (2001) Should flood insurance be mandatory? Insights in the wake of the 1997 New Year's Day flood in Reno-Sparks, Nevada. Applied Geography, 21, 199221.

[5] Ingirige, B. and Wedawatta, G. (2011) Impacts of flood hazards on small and medium sized companies. In: Lamond, J.E., Booth, C.A., Hammond, F. 
and Proverbs, D.G. (Editors) Flood Hazards: Impacts and Responses for the Built Environment. CRC Press - Taylor and Francis Group, London, 269-278.

[6] Bell, D. (2011) Impacts of flooding in the built environment. In: Lamond, J.E., Booth, C.A., Hammond, F. and Proverbs, D.G. (Editors) Flood Hazards: Impacts and Responses for the Built Environment. CRC Press Taylor and Francis Group, London, 37-51.

[7] Schelfaut, K., Pannemans, B., van der Craats I., Krywkow, J., Mysiak, J. and Cools, J. (2011) Bringing flood resilience into practice: the FREEMAN project. Environmental Science and Policy, 14, 825-833.

[8] Charlesworth, S.M. and Booth, C.A. (2012) Water resources issues and solutions for the built environment: too little versus too much. In: Booth, C.A., Hammond, F., Lamond, J.E. and Proverbs, D.G. (Editors) Solutions to Climate Change Challenges for the Built Environment. WileyBlackwells, Oxford, 237-250.

[9] Kelman, I. and Spence, R. (2004) An overview of flood actions on buildings. Engineering Geology, 73, 297-309.

[10] Bowker, P. (2007) Flood resistance and resilience solutions: an R\&D scoping study. R\&D Technical Report. DEFRA: London.

[11] Rose, C.B., Proverbs, D.G., Manktelow, K.I. and Booth, C.A. (2011) Improving community resilience: education, empowerment or encouragement? In: Lamond, J.E., Booth, C.A., Hammond, F. \& Proverbs, D.G. (Editors) Flood Hazards: Impacts and Responses for the Built Environment. Taylor and Francis Group, London, 305-313.

[12] Harries, T. (2011) Why most "at risk" homeowners do not protect their homes from flooding. In: Lamond, J.E., Booth, C.A., Hammond, F. and Proverbs, D.G. (Editors) Flood Hazards: Impacts and Responses for the Built Environment. CRC Press - Taylor and Francis Group, London, 327341.

[13] Tapsell, S. and Tunstall, S. (2008) "I wish I'd never heard of Banbury": the relationship between "place" and the health impacts from flooding. Health and Place, 14, 133-154.

[14] Dhonau, M. and Lamond, J.E. (2011) Property-level flood protection: case studies of successful schemes. In: Lamond, J.E., Booth, C.A., Hammond, F. \& Proverbs, D.G. (Editors) Flood Hazards: Impacts and Responses for the Built Environment. CRC Press - Taylor and Francis Group, London, 291303.

[15] Beddoes, D.W. and Booth, C.A. (2011) Property level flood resistance versus resilience measures: a novel approach. International Journal of Safety and Security Engineering, 1, 162-181.

[16] Johnson, M. (2011) Protection and performance of flooded buildings. In: Lamond, J.E., Booth, C.A., Hammond, F. and Proverbs, D.G. (Editors) Flood Hazards: Impacts and Responses for the Built Environment. CRC Press - Taylor and Francis Group, London, 259-267.

[17] Proverbs, D. and Soetanto, R. (2004) Flood Damaged Property-A Guide to Repair. Blackwell: Oxford. 
[18] Langton, D. (2011) Spon `s Architects`and Builders`Price Book 2011. Abingdon: Spon Press.

[19] http://www.safeguardeurope.com/pdf datasheets/sentry-twin-hla.pdf

[20] http://www.screwfix.com/p/door-guard-white-898-x-755mm/33363? requestid $=2045312$

[21] http://www.floodguards.com/floodguards.aspx

[22] Garvin, S., Reid, J. and Scott, M. (2005) Standards for the repair of buildings following flooding. London: CIRIA.

[23] Harries, T. (2007) Householder responses to flood risk; the consequences of the search for ontological security. Unpublished PhD Thesis, Middlesex University, UK.

[24] www.aviva.co.uk

[25] Defra (2008) Consultation on policy options for promoting property-level flood protection and resilience. DEFRA: London.

[26] http://www.environment-agency.gov.uk/news/135003.aspx?page=2\&month $=11$ \&year $=2011$ \& coverage $=$ Anglian

[27] Proverbs, D.G. and Lamond, J.E. (2008) The barriers to resilient reinstatement of flood damaged homes. In: International Group for Research and Information on Post-Disaster Construction (2008) $4^{\text {th }}$ International i-Rec Conference 2008 Building Resilience: achieving effective post-disaster reconstruction: April 30-May 2, 2008, Christchurch, New Zealand. 